\title{
Antiproliferative activity of protein hydrolysates derived from fish by-products on human colon and breast cancer cells.
}

\section{Abstract}

The consumption of fish is encouraged in dietary guidelines because of its association with health benefits; however, fish processing generates by-products (gills, bones, skin, head), which can rise up to $50-60 \%$ of fish weight after filleting. The investigation of bioactivity of fish by-products and subsequent utilization for the development of high added-value food ingredients and/or supplements will reduce waste and create new products of high nutritional value. We studied the antiproliferative activity of fish by-product protein hydrolysates $(\mathrm{FPH})$ on human colon and breast cancer cells. A total of 6 Meagres "Argirosomus Regius" (1256.45 $\pm 232.32 \mathrm{~g})$ and 16 Gilthead Sea Breams "Sparus Aurata" (403.47 $\pm 72.92 \mathrm{~g}$ ) were obtained by HCMR Institute in Crete, Greece. The fins, skin, bones, head, and gills were isolated, lyophilized, homogenized and stored separately at $-80^{\circ} \mathrm{C}$. The protein hydrolysates from each byproduct were prepared using a $\mathrm{pH}$ extraction method. Human colorectal adenocarcinoma cells (COLO320 cells) and human breast adenocarcinoma cells (MCF7A cells) were treated with different FPH for 48 hours, and cellular proliferation was measured using the MTT assay. Results are given as mean percentage of triplicate independent analyses. Statistical significance of growth inhibition was estimated following Wilcoxon Signed-Ranks test with $\alpha=0.05$. In COLO320 cells, FPH induced a the significant antiproliferative activity at $0.5 \mathrm{~g} / \mathrm{L}$. Specifically, FPH from bones, gills and skin of Meagre showed a growth inhibition of $23.7 \%, 9.9 \%$ and $26.4 \%$, respectively, after $48 \mathrm{~h}$ of treatment. The inhibition by the same by-products from the Gilthead Sea bream was $24.6 \%, 21.9 \%$ and $26.4 \%$, respectively after $48 \mathrm{~h}$. In MCF7A cells, FPH exerted a significant growth inhibition at $1 \mathrm{~g} / \mathrm{L}$. The skin and fins of Meagre induced a growth inhibition of $25.5 \%$ and $39.0 \%$ respectively; the gills, skin and fins of Gilthead Sea Bream showed a growth inhibition of $28.5 \%, 47.1 \%$ and $39.6 \%$, respectively, after $48 \mathrm{~h}$. These values were in the same range with etoposide (reference anticancer molecule) in the concentration of $3.1 \mu \mathrm{M}$ for COLO320 cells and $50 \mu \mathrm{M}$ for MCF7A. These preliminary data suggest that certain fish by-products could represent a source of anticancer peptides and may cause growth inhibition of human cancer cells. The isolation of responsible bioactive peptides from fish byproducts and the integration of them into food supplements can have beneficial effects on human health.

\section{Conflict of Interest}

There is no conflict of interest. 